\title{
DNA polymorphisms in the human tyrosine hydroxylase/insulin/ insulin-like growth factor II chromosomal region in relation to glucose and insulin responses
}

\author{
M.Sten-Linder ${ }^{1}$, A. Wedell ${ }^{1}$, L. Iselius ${ }^{2}$, S. Efendic ${ }^{3}$, R. Luft ${ }^{3}$ and H.Luthman ${ }^{1}$ \\ Departments of ${ }^{1}$ Clinical Genetics, ${ }^{2}$ Surgery and ${ }^{3}$ Endocrinology, Karolinska Institute, Karolinska Hospital, Stockholm, Sweden
}

Summary. The feasibility of disease association studies using polymorphic DNA markers in the tyrosine hydroxylase/insulin/insulin-like growth factor II chromosomal region was indicated by a high degree of linkage disequilibrium found in haplotypes. Haplotypes were resolved in the parents from Scandinavian nuclear families by studying the segregation of eight DNA polymorphisms. Comparison of observed vs expected frequencies of haplotypes, as well as pairwise measures of linkage disequilibrium, indicated a high degree of linkage disequilibrium. Five restriction fragment length polymorphisms linked to the tyrosine hydroxylase/insulin/ insulin growth factor II region of chromosome 11 were investigated in relation to Type 2 (non-insulin-dependent) diabetes mellitus, and to glucose and insulin responses to glu- cose infusion in healthy subjects. No significant differences in genotype frequencies between Type 2 diabetic $(n=53)$ and healthy subjects $(n=106)$ were found. A significant association $(p<0.001)$ was initially found between genotypes defined by a PstI polymorphism located 5' of the tyrosine hydroxylase gene and the early glucose response to a standardized glucose infusion test in healthy subjects. However, a follow-up study of 112 healthy individuals failed to confirm this finding.

Key words: Type 2 (non-insulin dependent) diabetes mellitus, glucose infusion test, insulin, tyrosine hydroxylase, insulin-like growth factor II, DNA polymorphisms, linkage disequilibrium.
Type 2 (non-insulin-dependent) diabetes mellitus is a common, heterogeneous disorder with a multifactorial aetiology, including a strong genetic component [1-4]. Several studies have suggested that impaired insulin secretion is an early defect in the development of the disease [5-8], and it has been shown that insulin release is genetically regulated [9]. Contributions of deficiencies in insulin gene function for impaired insulin secretion, and for the development of Type 2 diabetes can be addressed by population association studies. Association studies have hitherto been mainly focused on a variable number of tandem repeat (VNTR) polymorphism located near the $5^{\prime}$ end of the insulin gene. The conclusion of these studies is that no association can be found between this DNA polymorphism and manifest Type 2 diabetes $[10,11]$. However, a study of healthy Italian subjects had suggested an association between the long alleles of the VNTR polymorphism and a reduced ability, following glucose infusion, to secrete insulin [12].

Establishment of linkage disequilibrium in a chromosomal region is important for determining the feasibility of disease association studies between susceptibility genes and DNA markers. The tyrosine hydroxylase (TH), insulin (INS), and insulin-like growth factor II (IGF-II) genes are located within 55 kilobase pairs $(\mathrm{kb})$ on the short arm of chromosome $11[13,14]$. Earlier studies of linkage equilibrium relationships in this region have shown conflicting results $[15,16]$.

In previous studies, multiple DNA polymorphisms in the TH/INS/IGF-II chromosomal region have been examined in mixed Caucasian or Chinese American populations [15-17]. The studies of Cox et al. [16] and Xiang et al. [17] were based on statistically deduced haplotypes. In the present study, we have used family data to deduce the haplotypes in the genetically homogenous Scandinavian population. These haplotypes were used to determine the degree of linkage disequilibrium in the TH/INS/IGF-II chromosomal region. Furthermore, we have examined whether multiple DNA polymorphisms in the insulin gene region are associated with Type 2 diabetes or with variations in glucose and insulin responses to a standardized glucose infusion test in healthy subjects. 
Table 1. Clinical features of the subjects used in the genotype analysis

\begin{tabular}{lll}
\hline & Diabetic subjects & Healthy subjects \\
\hline$n$ & 53 & 106 \\
Sex $(\mathrm{M} / \mathrm{F})$ & $34 / 19$ & $62 / 44$ \\
Age $($ years $)$ & $53.5(39-70)$ & $45.2(21-72)$ \\
Body mass index $\left(\mathrm{kg} / \mathrm{m}^{2}\right)$ & $24.3(18.1-30.8)$ & $22.7(17.2-28.1)$ \\
Fasting plasma glucose & & \\
$\quad$ (mmol/) & $8.4(3.7-17.7)$ & $4.1(2.8-4.9)$ \\
Age at diagnosis (years) & $47.4(29-66)$ & \\
Present therapy: & & \\
$\quad$ Diet $(n)$ & 21 & \\
$\quad$ Sulphonylureas $(n)$ & 15 & \\
$\quad$ Insulin $(n)$ & 17 & \\
\hline
\end{tabular}

Values are means with ranges within parentheses

\section{Subjects and methods}

\section{Subjects}

For the haplotype analysis, a total of 209 subjects from 54 Scandinavian nuclear families were studied. The majority of the families were ascertained through a parent with Type 2 diabetes. Haplotypes were determined for a total of 99 unrelated parents, 42 were patients with Type 2 diabetes ( 23 males and 19 females; mean age 53.8 years, range 39-70; mean BMI $24.0 \mathrm{~kg} / \mathrm{m}^{2}$, range $\left.18.1-30.8\right)$ and 57 were healthy individuals ( 26 males and 31 females; mean age 51.3 years, range $32-72$; mean $\mathrm{BMT} 23.4 \mathrm{~kg} / \mathrm{m}^{2}$, range $18.1-28.1$ ).

Genotypes were determined in an additional group of 58 unrelated Scandinavians; 9 male patients with Type 2 diabetes ( 8 treated with diet, 1 treated with oral hypoglycaemic therapy) and 49 healthy individuals ( 36 males and 13 females). Characteristics of the groups used in the genotype analysis are summarized in Table 1. Mainly non-obese diabetic subjects were chosen (45 out of 53 had BMI $<28$ ), since genetic factors have been found to be more prominent in non-obese than in obese Type 2 diabetes subjects [2]. Type 2 diabetes was diagnosed according to the World Health Organization criteria, as described earlier [18]. The healthy individuals all had a fasting blood glucose of less than $5.2 \mathrm{mmol} / \mathrm{l}$. The follow-up study of the PstI-A polymorphism comprised 112 healthy unrelated Scandinavian men, mean age 36.7 years (range 20-47), mean BMI $23.8 \mathrm{~kg} / \mathrm{m}^{2}$ (range $17.2-30.0$ ), mean fasting glucose $4.4 \mathrm{mmol} / 1$ (range 3.1-5.1). All participating individuals gave informed consent to this study, which was conducted with the approval of the Ethics Committee at the Karolinska Hospital.

\section{Glucose infusion test}

The glucose infusion test was performed in the morning after 8-12 h of fasting. A rapid injection of $500 \mathrm{mg}$ glucose per $\mathrm{kg}$ body weight was immediately followed by a glucose infusion at a rate of $20 \mathrm{mg} \cdot \mathrm{kg}^{-1} \cdot \mathrm{min}^{-1}$ for $60 \mathrm{~min}$. Venous blood samples were drawn at $0,5,10,20,30,40,50,60,80,100$, and $120 \mathrm{~min}$ for determination of glucose and immunoreactive insulin (IRI) [19].

\section{DNA analysis}

The DNA polymorphisms studied and the probes used are listed in Table 2 [20-25]. DNA isolated from peripheral leukocytes [26] was digested with restriction enzymes PstI, RsaI, DraI, TaqI, PvuII, BamHI, or SacI, and analysed by Southern blotting [27] as previously described [18]. The genomic clones phINS 500, phINS-1, $\lambda$ HI-2 and phINS 311, as well as the cDNA clone phIGF2 were kindly provided by Dr. G. I. Bell, University of Chicago (Chicago, Ill., USA). The clone phINS E-22 is a subcloned EcoRI $2.2 \mathrm{~kb}$ fragment from $\lambda \mathrm{HI}-2$, the clone phINS 12-31 is a subcloned 721 base pair bp) PvuII/PvuII fragment of phINS-1, and 500-5 is a PstI/PstI fragment of $0.5 \mathrm{~kb}$ isolated from phINS 500 (Fig. 1). The 3-allele PstI-A polymorphism is the result of two polymorphic sites. There are no indications of a VNTR polymorphism giving rise to the three PstI alleles, since the 500-5 probe did not reveal a VNTR polymorphism with any of 10 other enzymes tested (BamHI, BgIII, DraI, EcoRI, HindIII, KpnI, RsaI, SacI, TaqI, XbaI). The follow-up study of the PstI-A polymorphism was conducted with PstI digestion of polymerase chain reaction products generated by amplification of genomic DNA by primers TH1 5'-GCCATGCAGAGCTTCACCAG-3' and TH2 5'-CTGCTTGGCGTCCAGCTCAG-3'. Amplification of $200 \mathrm{ng}$ genomic DNA using $0.5 \mu \mathrm{mol} / 1$ of each primer was performed. After an initial denaturation at $96^{\circ} \mathrm{C}$ for $3 \mathrm{~min}, 30$ cycles were performed, including denaturation at $96^{\circ} \mathrm{C}$ for $1 \mathrm{~min}$, primer annealing at $60^{\circ} \mathrm{C}$ for $30 \mathrm{~s}$, and primer extension at $72^{\circ} \mathrm{C}$ for $15 \mathrm{~min}$. The polymerase chain reaction buffer contained $1.0 \mathrm{mmol} / 1 \mathrm{MgCl}_{2}, 0.2 \mathrm{mmol} / \mathrm{l}$ of each of the four deoxynucleotide triphosphates (dATP, dCTP, dGTP and dTTP), $50 \mathrm{mmol} / 1 \mathrm{KCl}, 10 \mathrm{mmol} / 1$ Tris-HCl pH 8.4 at $70^{\circ} \mathrm{C}$, and $0.1 \%$ Tween 20. Two units Taq polymerase (Perkin-Elmer Cetus, Norwalk, Conn., USA) were used for each $100 \mu$ l reaction.

\section{Statistical analysis}

Comparison between observed and expected haplotype frequencies, as well as the comparison of haplotype distributions in diabetic vs normal chromosomes, were performed using chi-square analysis. Cells with expected numbers less than four were pooled to one group.

The values of the linkage disequilibrium parameter $D^{\prime}$ $\left(\mathrm{D}^{\prime}=\mathrm{D} / \mathrm{D}_{\max }\right)$ and the chi-square tests on $\mathrm{D}$ were calculated as earlier described [28-30]. In our calculations $\mathrm{D}^{\prime}$ is positive when two long alleles are associated and negative when the long allele at one locus is associated with the short allele at the second locus (except for the VNTR where allele 1 is the short allele). The level $p<0.005$ was considered as the minimum requirement for significance in order to adjust for multiple comparisons.

Genotype frequencies of the diabetic and control subjects were compared using $2 \times 3$ or $2 \times 2$ contingency tables and chi-square analysis of independence. In these analyses, cells with expected numbers less than four were pooled to one group.

The amounts of glucose and IRI secreted between $0-10 \mathrm{~min}, 10$ $60 \mathrm{~min}$, and 60-120 min during the glucose infusion test were determined as the areas under the concentration curves for each time period. In order to reduce skewness, some variables were logarithmically transformed prior to statistical analysis. The variables were then adjusted using stepwise multiple regression on age, sex, and in a second step, BMI. Only significant terms $(p<0.05)$ were retained in the regression equation. One-way analysis of variance or Student's $t$-test was performed on the adjusted variables, to test the null hypothesis that TH/INS/IGF-II genotypes are not associated with variations in glucose and insulin responses to glucose infusion test in healthy subjects. In order to compensate for multiple comparisons, $p<0.005$ was chosen as the minimum requirement for significance in the initial study comprising several RFLP systems.

\section{Results}

DNA polymorphisms in the TH/INS/IGF-II chromosomal region

Eight DNA markers distributed over $50 \mathrm{~kb}$ in the TH/INS/IGF-II gene region of chromosome 11 were used in the haplotype analysis (Table 2, Fig. 1). Four of the markers, the RsaI, PstI-A, TaqI, and DraI RFLPs, are located within a few $\mathrm{kb}$ in the $5^{\prime}$ flanking region of the TH gene $[21,25]$. The two longer PstI-A alleles were considered as one allele, since with our probes, the presence of a short allele prevents the analysis of the second polymorphic site. The PstI-B, BamHI, and SacI sites were localized 
Table 2. DNA polymorphisms in the tyrosine hydroxylase/insulin/insulin-like growth factor II (TH/INS/IGF-II) chromosomal region. No significant differences were found between the allele frequencies of Type 2 (non-insulin-dependent) diabetic patients and healthy subjects using chi-square analysis

\begin{tabular}{|c|c|c|c|c|c|c|}
\hline \multirow[t]{2}{*}{ RFLP } & \multirow[t]{2}{*}{ Probe } & \multicolumn{2}{|c|}{ Allele } & \multicolumn{2}{|c|}{ Frequency } & \multirow{2}{*}{$\begin{array}{l}\text { Refer- } \\
\text { ence }\end{array}$} \\
\hline & & No. & Size $^{a}$ & $\begin{array}{l}\text { Diabetic } \\
\text { patients } \\
\left(n=53^{\mathrm{b}}\right)\end{array}$ & $\begin{array}{l}\text { Healthy } \\
\text { subjects } \\
\left(n=106^{\mathrm{b}}\right)\end{array}$ & \\
\hline RsaI & $500-5$ & $\begin{array}{l}1 \\
2\end{array}$ & $\begin{array}{l}1.45 \\
1.25\end{array}$ & $\begin{array}{l}0.35 \\
0.65\end{array}$ & $\begin{array}{l}0.37 \\
0.63\end{array}$ & [21] \\
\hline PstI-A & $500-5$ & $\begin{array}{l}\text { A-1 } \\
\text { A-2 } \\
3\end{array}$ & $\begin{array}{l}2.8 \\
1.5 \\
0.5\end{array}$ & $\begin{array}{l}0.05 \\
0.31 \\
0.64\end{array}$ & $\begin{array}{l}0.09 \\
0.30 \\
0.61\end{array}$ & [25] \\
\hline TaqI & $\begin{array}{l}\text { phINS } \\
500\end{array}$ & $\begin{array}{l}1 \\
2 \\
3\end{array}$ & $\begin{array}{l}4.8 \\
2.8+2.0 \\
2.8^{\mathrm{d}}\end{array}$ & $\begin{array}{l}0.12 \\
0.88 \\
0\end{array}$ & $\begin{array}{l}0.12 \\
0.87 \\
0.01\end{array}$ & [21] \\
\hline DraI & $500-5$ & $\begin{array}{l}1 \\
2\end{array}$ & $\begin{array}{r}10.3 \\
8.7\end{array}$ & $\begin{array}{l}0.64 \\
0.36\end{array}$ & $\begin{array}{l}0.63 \\
0.37\end{array}$ & {$[25]$} \\
\hline PstI-B & $\begin{array}{l}\text { phINS } \\
\text { E-22 }\end{array}$ & $\begin{array}{l}1 \\
2\end{array}$ & $\begin{array}{l}1.3 \\
0.7+0.6\end{array}$ & $\begin{array}{l}0.45 \\
0.55\end{array}$ & $\begin{array}{l}0.47 \\
0.53\end{array}$ & [23] \\
\hline $\begin{array}{l}\text { PvuII } \\
\text { (VNTR) }\end{array}$ & $\begin{array}{l}\text { phINS } \\
12-31\end{array}$ & $\begin{array}{l}1 \\
2 \\
3\end{array}$ & $\begin{array}{l}0.7-1.0 \\
1.5-1.8 \\
2.1-2.4\end{array}$ & $\begin{array}{l}0.68 \\
0 \\
0.32\end{array}$ & $\begin{array}{l}0.77 \\
0.01 \\
0.22\end{array}$ & {$[20]$} \\
\hline BamHI & $\begin{array}{l}\text { phINS } \\
311\end{array}$ & $\begin{array}{l}1 \\
2\end{array}$ & $\begin{array}{l}2.2 \\
1.2\end{array}$ & $\begin{array}{l}0.68 \\
0.32\end{array}$ & $\begin{array}{l}0.63 \\
0.37\end{array}$ & {$[22]$} \\
\hline SacI & phIGF2 & $\begin{array}{l}1 \\
2\end{array}$ & $\begin{array}{r}12.5 \\
8.5\end{array}$ & $\begin{array}{l}0.26 \\
0.74\end{array}$ & $\begin{array}{l}0.26 \\
0.74\end{array}$ & {$[24]$} \\
\hline
\end{tabular}

${ }^{a}$ Size is expressed in $\mathrm{kb}$ (kilobase-pairs).

b The RsaI, DraI, and the variable number of tandem repeat (VNTR) polymorphisms were only used in the haplotype analysis, thus these allele frequencies are based on 42 diabetic patients and 57 healthy subjects.

c The PstI alleles A-1 and A-2 are referred to as A in the statistical comparisons, since in our analysis the presence of a short allele prevents the analysis of this second polymorphic site.

${ }^{\mathrm{d}}$ The TaqI allele $3(2.8 \mathrm{~kb})$, with a missing $2.0 \mathrm{~kb}$ fragment, was suspected to be the result of a deletion $5^{\prime}$ of the TH gene, but the phINS 500 probe detected no abnormal DNA fragments with ten other enzymes (BamHI, BglII, DraI, EcoRI, HindII, KpnI, PstI, RsaI, SacI, XbaI)

within the region by multiple probing and comparison to the known DNA sequences (Fig.1). The VNTR polymorphism is located $363 \mathrm{bp} 5^{\prime}$ of the insulin gene transcription initiation site [20].

The rare TaqI allele $3(2.8 \mathrm{~kb})$ with a missing $2.0 \mathrm{~kb}$ band, was suspected to be the result of a deletion $5^{\prime}$ of the TH gene, but pHINS 500 detected no abnormal fragment patterns with ten other enzymes (BamHI, BglII, DraI, EcoRI, HindIII, KpnI, PstI, RsaI, SacI, XbaI). The nondiabetic father and two children carrying this allele were all healthy.

\section{Determination of haplotype frequencies}

Haplotypes for the DNA markers were determined in unrelated parents of Scandinavian nuclear families using the offspring genotypes with the assumption that no recombination occurred in the families between these markers. There were no indications of non-paternity with the eight markers tested, or by the segregation of insulin receptor gene haplotypes with 34 different alleles [30]. Complete haplotypes were successfully determined for 84 individuals (34 diabetic and 50 healthy subjects). Twenty-three different complete haplotypes were observed (Table 3). The DraI and RsaI RFLPs showed a complete linkage disequilibrium with Pst-A in these individuals, and was therefore excluded in the further analyses.

The overall haplotype distribution of Type 2 diabetes and normal chromosomes was compared using chi-square analysis. Prior to analysis, all but the six most common groups (haplotype no.3, 4, 13, 14, 20 and 22) were pooled in order to achieve cells with expected frequencies of at least four, thus the chi-square analysis is insensitive. No significant difference in haplotype distribution between Type 2 diabetes and normal chromosomes was detected $\left(\chi^{2}=4.40,6 d f\right)$.

\section{Estimation of linkage disequilibrium in the TH/INS/IGF-II chromosomal region}

The expected haplotype frequencies - assuming linkage equilibrium - were calculated as the product of their compound marker allele frequencies in the healthy parents included in the haplotype study. The level of overall linkage disequilibrium was estimated by chi-square analysis of the observed vs the expected haplotype frequencies. All cells with expected numbers less than four in either normal or Type 2 diabetes chromosomes were pooled to one group prior to the analysis. The observed frequency distribution of the haplotypes in both healthy subjects $\left(\chi^{2}=14.25,4 d f\right.$, $p<0.01)$ and Type 2 diabetic patients $\left(\chi^{2}=15.31,4 d f\right.$, $p<0.005$ ) differed significantly from the expected distribution, suggesting overall linkage disequilibrium in the TH/INS/IGF-II chromosomal region.

The parameter $\mathrm{D}^{\prime}$ was determined to obtain measures of linkage disequilibrium between RFLP pairs (Table 4). Data from both complete and partial haplotypes were used for these calculations. The rare TaqI 3 -allele and the VNTR 2-allele were excluded in these analyses. The TaqI:BamHI pair and the PstI-B:SacI pair showed significant linkage disequilibrium in chromosomes from both normal and Type 2 diabetic subjects, despite the relatively large physical distance between these markers. Significant linkage disequilibrium was also detected between most of the adjacent RFLP sites.

We conclude from these studies that, since the TH/INS/ IGF-II gene region shows a high degree of linkage disequilibrium, DNA polymorphisms in this region can be used in disease association studies of this population.

\section{Genotype distribution in Type 2 diabetic patients and healthy subjects}

We used an enlarged study group of Type 2 diabetic patients $(n=53)$ and healthy control subjects $(n=106)$ (Table 1) for the analysis of genotype distribution. Five DNA polymorphisms distributed over the gene region were selected for the analysis. The distribution of these RFLP genotypes are shown in Table 5. The genotype distributions were all in Hardy-Weinberg equilibrium, as tested by chi-square analysis. No significant differences in 
500-5

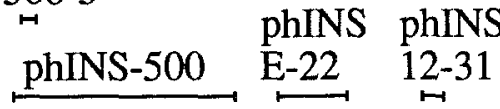

\section{phINS-311}

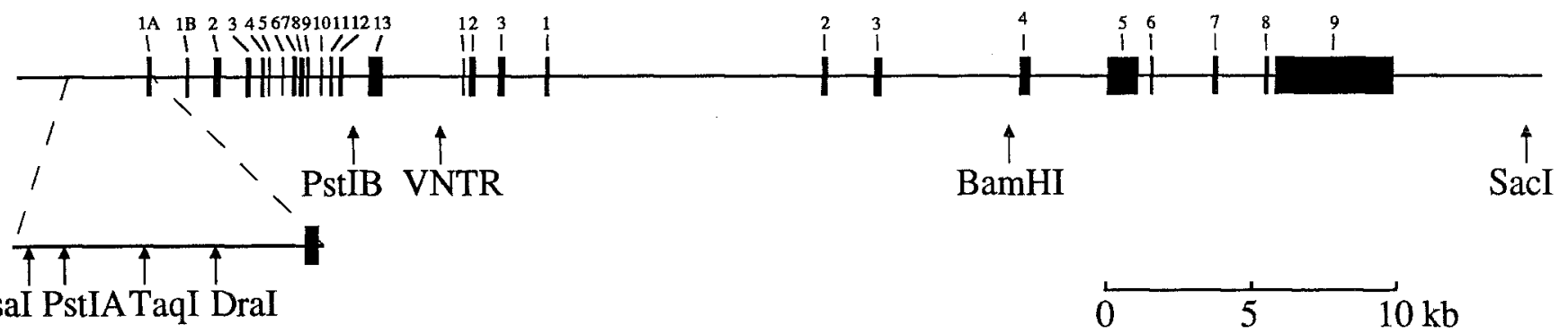

Fig. 1. Map of the human tyrosine hydroxylase/insulin/insulin-like growth factor II (TH/INS/IGF-II) chromosomal region. The exons of the three genes are symbolized by filled boxes and the direction of their transcription denoted by the horizontal arrows. Locations of the hybridization probes are indicated by the extensions of the bars. Probe phIGF-II encompass exons $3,7,8$, and approximately 1 kilobase $(\mathrm{kb})$ of exon 9 [34]. DNA polymorphisms used in this study are

allele frequencies (Table 2) or genotype distributions (Table 5) were found between the diabetic and healthy groups, using chi-square analysis.

Restricting the control group to individuals at least 45 years old ( $n=54$, mean age 55.2 years), to reduce the risk of including individuals who may later develop Type 2 diabetes, did not affect the outcome of the statistical analysis (data not shown).

shown by the vertical arrows. The 3-allele system generated by PstIA is composed of two polymorphic sites, the site used in our analysis is denoted by an arrow. The second PstI-A site is located approximately $1 \mathrm{~kb} 5^{\prime}$ of this site. Information for this figure was obtained from $[14,21,23,25,35-39]$ and unpublished observations (Sten-Linder $\mathrm{M}$ and Luthman $\mathrm{H}$ )

Glucose and insulin responses to glucose infusion in different genotype groups of healthy subjects

The possible association between TH/INS/IGF-II RFLP genotypes and variations in glucose and insulin responses to glucose infusion in healthy subjects was investigated. We compared the insulin and glucose concentrations during a standardized glucose infusion test between the dif-

Table 3. Frequency distribution of the tyrosine hydroxylase/insulin/insulin-like growth factor II (TH/INS/IGF-II) region haplotypes in Type 2 (non-insulin-dependent) diabetic patients and healthy subjects. Expected values assuming equilibrium were calculated as the products of the frequencies of composite alleles in the healthy subjects

\begin{tabular}{|c|c|c|c|c|c|c|c|c|c|c|c|c|c|}
\hline \multirow{2}{*}{$\begin{array}{l}\text { Identifi- } \\
\text { cation }\end{array}$} & \multicolumn{8}{|c|}{ Haplotype } & \multicolumn{3}{|c|}{ Type 2 diabetic patients } & \multicolumn{2}{|c|}{ Normal subjects } \\
\hline & $\overline{\text { RsaI }}$ & PstI-A & TaqI & Dral & PstI-B & VNTR & BamHI & SacI & $n$ & $\begin{array}{l}\text { Observed } \\
\text { freq. } \%\end{array}$ & $n$ & $\begin{array}{l}\text { Observed } \\
\text { freq. } \%\end{array}$ & $\begin{array}{l}\text { Expected } \\
\text { freq. } \%\end{array}$ \\
\hline 1 & 1 & A & 2 & 2 & 1 & 1 & 1 & 1 & 0 & 0.00 & 3 & 3.00 & 1.34 \\
\hline 3 & 1 & A & 2 & 2 & 1 & 1 & 2 & 2 & 4 & 5.88 & 11 & 11.00 & 3.52 \\
\hline 4 & 1 & $\mathrm{~A}$ & 2 & 2 & 1 & 3 & 1 & 1 & 7 & 10.29 & 5 & 5.00 & 0.38 \\
\hline 5 & 1 & A & 2 & 2 & 1 & 3 & 1 & 2 & 3 & 4.41 & 2 & 2.00 & 1.43 \\
\hline 8 & 1 & A & 2 & 2 & 2 & 1 & 2 & 2 & 2 & 2.94 & 7 & 7.00 & 3.12 \\
\hline 9 & 1 & A & 2 & 2 & 2 & 2 & 2 & 2 & 0 & 0.00 & 1 & 1.00 & 0.04 \\
\hline 10 & 1 & $\mathrm{~A}$ & 2 & 2 & 2 & 3 & 1 & 1 & 0 & 0.00 & 1 & 1.00 & 0.34 \\
\hline 11 & 1 & $\mathrm{~A}$ & 2 & 2 & 2 & 3 & 1 & 2 & 4 & 5.88 & 3 & 3.00 & 1.26 \\
\hline 12 & 2 & 3 & 1 & 1 & 2 & 1 & 2 & 1 & 1 & 1.47 & 0 & 0.00 & 0.29 \\
\hline 13 & 2 & 3 & 1 & 1 & 2 & 1 & 2 & 2 & 9 & 13.24 & 11 & 11.00 & 1.09 \\
\hline 18 & 2 & 3 & 2 & 1 & 1 & 3 & 1 & 2 & 3 & 4.41 & 4 & 4.00 & 2.45 \\
\hline 19 & 2 & 3 & 2 & 1 & 2 & 1 & 1. & 1 & 1 & 1.47 & 1 & 1.00 & 2.94 \\
\hline 20 & 2 & 3 & 2 & 1 & 2 & 1 & 1 & 2 & 14 & 20.59 & 21 & 21.00 & 11.03 \\
\hline 21 & 2 & 3 & 2 & 1 & 2 & 1 & 2 & 1 & 1 & 1.47 & 0 & 0.00 & 2.06 \\
\hline 22 & 2 & 3 & 2 & 1 & 2 & 1 & 2 & 2 & 3 & 4.41 & 8 & 8.00 & 7.74 \\
\hline \multirow[t]{2}{*}{23} & 2 & 3 & 2 & 1 & 2 & 3 & 1 & 2 & 2 & 2.94 & 4 & 4.00 & 3.13 \\
\hline & & & & & & & & & 68 & & 100 & & \\
\hline
\end{tabular}


Table 4. Standardized non-random association statistics, $\mathrm{D}^{\prime}$, between pairs of DNA polymorphisms in the tyrosine hydroxylase/insulin/insulin-like growth factor II (TH/INS/IGF-II) region in Type 2 (non-insulin-dependent) diabetic patients (above the diagonal) and healthy subjects (below the diagonal)

\begin{tabular}{|c|c|c|c|c|c|c|}
\hline Site & PstI-A & TaqI & PstI-B & VNTR & BamHI & SacI \\
\hline PstI-A & - & -1.00 & 0.35 & $-0.42^{b}$ & 0.23 & 0.02 \\
\hline TaqI & $-1.00^{\mathrm{a}}$ & - & $-1.00^{\mathrm{a}}$ & 1.00 & $-1.00^{b}$ & -0.65 \\
\hline PstI-B & $0.39^{\mathrm{b}}$ & $-1.00^{\mathrm{a}}$ & - & -0.39 & 0.42 & $0.74^{b}$ \\
\hline BamHI & -0.21 & $-1.00^{b}$ & 0.16 & $-1.00^{\mathrm{b}}$ & - & 0.67 \\
\hline SacI & 0.25 & -1.00 & $0.83^{b}$ & -0.19 & $1.00^{b}$ & - \\
\hline
\end{tabular}

${ }^{a} \mathrm{D}$ significantly different from $0(p<0.005)$;

${ }^{\mathrm{b}} \mathrm{D}$ significantly different from $0(p<0.001)$

VNTR, Variable number of tandem repeat

Table 5. Distribution of genotypes in Type 2 (non-insulin-dependent) diabetic patients $(n=53)$ and healthy control subjects $(n=106)$

\begin{tabular}{|c|c|c|c|c|c|c|}
\hline \multirow{2}{*}{\multicolumn{2}{|c|}{ Genotypes }} & \multicolumn{2}{|c|}{ Diabetic patients } & \multicolumn{3}{|c|}{ Control subjects } \\
\hline & & $\frac{n}{8}$ & $\frac{\text { (frequency) }}{(0.15)}$ & $\frac{n}{19}$ & \multicolumn{2}{|c|}{ (frequency) } \\
\hline PstI-A & $\begin{array}{l}\mathrm{A} / \mathrm{A} \\
\mathrm{A} / 3 \\
3 / 3\end{array}$ & $\begin{array}{r}8 \\
22 \\
23\end{array}$ & $\begin{array}{l}(0.15) \\
(0.44) \\
(0.43)\end{array}$ & $\begin{array}{l}19 \\
44 \\
43\end{array}$ & $\begin{array}{l}(0.18) \\
(0.41) \\
(0.41)\end{array}$ & $\begin{array}{l}\chi^{2}=0.24 \\
p=0.89\end{array}$ \\
\hline TaqI & $\begin{array}{l}1 / 1 \\
1 / 2 \\
2 / 2 \\
1 / 3\end{array}$ & $\begin{array}{r}1 \\
11 \\
41 \\
0\end{array}$ & $\begin{array}{l}(0.02) \\
(0.21) \\
(0.77)\end{array}$ & $\begin{array}{r}2 \\
21 \\
82 \\
1\end{array}$ & $\begin{array}{l}(0.02) \\
(0.20) \\
(0.77) \\
(0.01)\end{array}$ & $\begin{array}{l}\chi^{2}=0.04^{\mathrm{a}} \\
p=0.84\end{array}$ \\
\hline PstI-B & $\begin{array}{l}1 / 1 \\
1 / 2 \\
2 / 2\end{array}$ & $\begin{array}{l}11 \\
26 \\
16\end{array}$ & $\begin{array}{l}(0.21) \\
(0.49) \\
(0.30)\end{array}$ & $\begin{array}{l}25 \\
49 \\
32\end{array}$ & $\begin{array}{l}(0.24) \\
(0.46) \\
(0.30)\end{array}$ & $\begin{array}{l}\chi^{2}=0.19 \\
p=0.91\end{array}$ \\
\hline BamHI & $\begin{array}{l}1 / 1 \\
1 / 2 \\
2 / 2\end{array}$ & $\begin{array}{r}27 \\
18 \\
8\end{array}$ & $\begin{array}{l}(0.51) \\
(0.34) \\
(0.15)\end{array}$ & $\begin{array}{l}45 \\
44 \\
17\end{array}$ & $\begin{array}{l}(0.42) \\
(0.42) \\
(0.16)\end{array}$ & $\begin{array}{l}\chi^{2}=1.10 \\
p=0.58\end{array}$ \\
\hline SacI & $\begin{array}{l}1 / 1 \\
1 / 2 \\
2 / 2\end{array}$ & $\begin{array}{r}2 \\
24 \\
27\end{array}$ & $\begin{array}{l}(0.04) \\
(0.45) \\
(0.51)\end{array}$ & $\begin{array}{l}10 \\
36 \\
60\end{array}$ & $\begin{array}{l}(0.09) \\
(0.34) \\
(0.57)\end{array}$ & $\begin{array}{l}\chi^{2}=2.91 \\
p=0.23\end{array}$ \\
\hline
\end{tabular}

${ }^{a}$ The TaqI $1 / 1,1 / 2$, and $1 / 3$ genotypes were pooled before performing the chi-square analysis in order to achieve an expected number of at least four in all groups

ferent genotype groups. The amounts of glucose and insulin were calculated as the areas under the concentration curves during different time periods of the test (Tables 6 and 7). Prior to statistical analysis, the variables were adjusted for effects associated with age, sex or BMI. The values from the glucose infusion test in the different genotype groups were compared using one-way analysis of variance or Student's $t$-test. In order to compensate for multiple comparisons, $p<0.005$ was chosen as the minimum requirement for significance. One association between genotypes and glucose infusion test variables was found at this level of significance. Subjects with different PstI-A genotypes displayed a small but highly significant difference in the plasma glucose levels attained during the first 10 min of infusion $(p<0.001)$ (Table 6). Significant differences in insulin (IRI) concentrations for the same time period were not observed (Table 7).

The reproducibility of the significant difference in the initial plasma glucose levels during glucose infusion in subjects with different PstI-A genotypes was tested in a follow-up study of 112 unrelated, healthy male subjects with fasting glucose below $5.2 \mathrm{mmol} / \mathrm{l}$ (see Subjects and methods for clinical characteristics). The same standardized glucose infusion test was performed on this group as for the subjects in the initial study. In contrast to the significant finding above, no significant differences in glucose or insulin concentrations during glucose infusion was found between the different PstI-A genotype groups (Table 8).

\section{Discussion}

The present study indicates a high degree of linkage disequilibrium in the TH/INS/IGF-II chromosomal region in the Scandinavian population. An almost total linkage disequilibrium was observed for three of the four RFLPs which are located physically close to each other $5^{\prime}$ of the TH gene (PstI-A, RsaI and DraI). The fourth RFLP (TaqI) in this cluster shows a somewhat weaker linkage disequilibrium. Since the TaqI 1-allele is relatively rare and is present on two similar haplotypes only, the TaqI polymorphism may be evolutionary more recent than the other polymorphisms in this chromosomal region. The TaqI:BamHI pair and the PstI-B:SacI pair showed significant linkage disequilibrium in chromosomes from both normal and Type 2 diabetic subjects, despite the relatively large physical distance between these markers. These observations suggest the absence of a high recombination rate in the INS $5^{\prime}$ VNTR, in accordance with the finding that VNTR polymorphisms show no increased interchromosomal recombination [31]. Our findings are in agreement with the study of Cox et al. [16], and support the conclusion that the use of population association studies to study correlations between markers from the TH/INS/IGF-II locus and disease are feasible.

A study of haplotypes of the TH/INS/IGF-II region constructed by statistical methods in unrelated Chinese Americans [17], showed no statistically significant differences in haplotype frequencies between control and Type 2 diabetic subjects. In our study we found some haplotypes to be overrepresented in healthy subjects and some to be more common in Type 2 diabetic patients. However, the number of subjects carrying these haplotypes was too low to allow conclusive statistical evidence for an association with Type 2 diabetes.

Five different RFLP markers in the insulin gene region were used to investigate possible associations with Type 2 
Table 6. Glucose concentrations during the glucose infusion test (GIT) in the different genotype groups of 106 healthy subjects

\begin{tabular}{|c|c|c|c|c|c|c|c|c|c|}
\hline \multirow[t]{2}{*}{ Genotype } & \multirow[t]{2}{*}{$n$} & \multirow{2}{*}{\multicolumn{2}{|c|}{$\frac{\text { Fasting glucose }}{(\mathrm{mmol} / \mathrm{l})}$}} & \multicolumn{2}{|c|}{ GIT glucose area } & \multicolumn{2}{|c|}{ GIT glucose area } & \multicolumn{2}{|c|}{ GIT glucose area } \\
\hline & & & & $\times 10^{-2}$ & $0-10 \mathrm{~min}$ & $\times 10^{-2}$ & $10-60 \mathrm{~min}$ & $\times 10^{-2}$ & $60-120 \min$ \\
\hline \multicolumn{10}{|l|}{ PstI-A } \\
\hline $\mathrm{A} / \mathrm{A}$ & 19 & 4.2 & & 1.5 & & 9.7 & & 6.0 & \\
\hline $\mathrm{A} / 3$ & 44 & 4.1 & $F=0.95$ & 1.3 & $\mathrm{~F}=7.50^{\mathrm{b}}$ & 9.0 & $F=2.11$ & 5.7 & $F=0.03$ \\
\hline $3 / 3$ & 43 & 4.0 & $(2 ; 103)$ & 1.3 & $(2 ; 103)$ & 8.8 & $(2 ; 103)$ & 5.3 & $(2 ; 101)$ \\
\hline \multicolumn{10}{|l|}{ TaqI } \\
\hline $1 / 1$ & 2 & 4.2 & & 1.3 & & 9.4 & & 7.2 & \\
\hline $1 / 2$ & 21 & 4.1 & & 1.3 & & 9.0 & & 5.7 & \\
\hline $2 / 2$ & 82 & 4.1 & $t=0.08$ & 1.3 & $t=0.86$ & 9.0 & $t=0.12$ & 5.5 & $t=0.94$ \\
\hline $1 / 3$ & 1 & 4.6 & $(104)$ & 1.6 & $(104)$ & 10.7 & $(104)$ & 5.4 & $(102)$ \\
\hline \multicolumn{10}{|l|}{ PstI-B } \\
\hline $1 / 1$ & 25 & 4.1 & & 1.4 & & 9.2 & & 5.7 & \\
\hline $1 / 2$ & 49 & 4.2 & $\mathrm{~F}=1.93$ & 1.4 & $F=2.68$ & 9.1 & $F=0.92$ & 5.6 & $F=0.04$ \\
\hline $2 / 2$ & 32 & 4.0 & $(2 ; 103)$ & 1.3 & $(2 ; 103)$ & 8.7 & $(2 ; 103)$ & 5.5 & $(2 ; 101)$ \\
\hline \multicolumn{10}{|l|}{ BamHI } \\
\hline $1 / 1$ & 45 & 4.1 & & 1.4 & & 9.2 & & 5.5 & \\
\hline $1 / 2$ & 44 & 4.1 & $\mathrm{~F}=0.22$ & 1.3 & $F=0.49$ & 8.9 & $\mathrm{~F}=0.16$ & 5.6 & $\mathrm{~F}=0.41$ \\
\hline $2 / 2$ & 17 & 4.1 & $(2 ; 103)$ & 1.3 & $(2 ; 103)$ & 9.0 & $(2 ; 103)$ & 5.7 & $(2 ; 101)$ \\
\hline \multicolumn{10}{|l|}{ SacI } \\
\hline $1 / 1$ & 10 & 4.2 & & 1.4 & & 9.9 & & 6.0 & \\
\hline $1 / 2$ & 36 & 4.2 & $\mathrm{~F}=2.30$ & 1.3 & $\mathrm{~F}=1.93$ & 9.5 & $\mathrm{~F}=4.59^{\mathrm{a}}$ & 5.9 & $\mathrm{~F}=1.14$ \\
\hline $2 / 2$ & 60 & 4.0 & $(2 ; 103)$ & 1.3 & $(2 ; 103)$ & 8.6 & $(2 ; 103)$ & 5.3 & $(2 ; 101)$ \\
\hline
\end{tabular}

Values are arithmetic means for each group. The statistical analysis was made using one-way analysis of variance except for the TaqI polymorphism, where a Student's $t$-test was performed on the $2 / 2$

homozygote groups vs the $1 / 2,1 / 1$ and $1 / 3$ genotype groups. Degrees of freedom for $\mathrm{F}$ - and $t$-values are shown within parentheses ${ }^{\mathrm{a}} p<0.05,{ }^{\mathrm{b}} p<0.001$

Table 7. Insulin $\left(\mathrm{IRI}^{\mathrm{a}}\right)$ concentrations during the glucose infusion test (GIT) in the different genotypes of 106 healthy subjects

\begin{tabular}{|c|c|c|c|c|c|c|c|c|c|}
\hline \multirow[t]{2}{*}{ Genotype } & \multirow[t]{2}{*}{$n$} & \multicolumn{2}{|c|}{ Fasting IRI ${ }^{a}$} & \multicolumn{2}{|c|}{ GIT IRI $^{\mathrm{a}}$ area } & \multicolumn{2}{|c|}{ GIT IRI $^{\mathrm{a}}$ area } & \multicolumn{2}{|c|}{ GIT IRI $^{a}$ area } \\
\hline & & $\overline{(\mathrm{pmol} / \mathrm{l})}$ & $\times 10^{-2}$ & $\overline{\times 10^{-3}}$ & $0-10 \mathrm{~min}$ & $\times 10^{-3}$ & $10-60 \mathrm{~min}$ & $\times 10^{-3}$ & $60-120 \mathrm{~min}$ \\
\hline \multicolumn{10}{|l|}{ PstI-A } \\
\hline $\mathrm{A} / \mathrm{A}$ & 19 & 1.2 & & 4.0 & & 20.4 & & 26.5 & \\
\hline $\mathrm{A} / 3$ & 44 & 1.2 & $F=0.00$ & 3.3 & $F=0.26$ & 21.2 & $F=0.07$ & 30.3 & $\mathrm{~F}=0.09$ \\
\hline $3 / 3$ & 43 & 1.2 & $(2 ; 103)$ & 3.7 & $(2 ; 103)$ & 20.7 & $(2 ; 103)$ & 25.7 & $(2 ; 102)$ \\
\hline \multicolumn{10}{|l|}{ TaqI } \\
\hline $1 / 1$ & 2 & 1.0 & & 1.5 & & 11.2 & & 17.3 & \\
\hline $1 / 2$ & 21 & 1.2 & & 3.8 & & 20.1 & & 27.3 & \\
\hline $2 / 2$ & 82 & 1.2 & $t=0.03$ & 3.6 & $t=0.79$ & 21.2 & $t=1.10$ & 28.0 & $t=0.72$ \\
\hline $1 / 3$ & 1 & 1.4 & (104) & 3.5 & $(104)$ & 30.3 & $(104)$ & 41.2 & (103) \\
\hline \multicolumn{10}{|l|}{ PstI-B } \\
\hline $1 / 1$ & 25 & 1.2 & & 3.0 & & 18.1 & & 22.7 & \\
\hline $1 / 2$ & 49 & 1.3 & $F=0.80$ & 4.0 & $F=1.01$ & 21.8 & $F=1.28$ & 28.4 & $F=2.12$ \\
\hline $2 / 2$ & 32 & 1.2 & $(2 ; 103)$ & 3.5 & $(2 ; 103)$ & 21.5 & $(2 ; 103)$ & 30.6 & $(2 ; 102)$ \\
\hline \multicolumn{10}{|l|}{ BamHI } \\
\hline $1 / 1$ & 45 & 1.2 & & 3.8 & & 22.3 & & 30.6 & \\
\hline $1 / 2$ & 44 & 1.2 & $\mathrm{~F}=0.00$ & 3.6 & $\mathrm{~F}=0.72$ & 19.9 & $F=0.80$ & 25.0 & $F=1.05$ \\
\hline $2 / 2$ & 17 & 1.2 & $(2 ; 103)$ & 3.1 & $(2 ; 103)$ & 19.6 & $(2 ; 103)$ & 27.4 & $(2 ; 102)$ \\
\hline \multicolumn{10}{|l|}{ SacI } \\
\hline $1 / 1$ & 10 & 1.2 & & 2.6 & & 17.2 & & 24.0 & \\
\hline $1 / 2$ & 36 & 1.2 & $F=0.16$ & 3.1 & $\mathrm{~F}=3.10^{\mathrm{b}}$ & 19.2 & $F=1.41$ & 28.8 & $\mathrm{~F}=0.26$ \\
\hline $2 / 2$ & 60 & 1.2 & $(2 ; 103)$ & 4.1 & $(2 ; 103)$ & 22.5 & $(2 ; 103)$ & 27.8 & $(2 ; 102)$ \\
\hline
\end{tabular}

Values are arithmetic means for each group. The statistical analysis was made using one-way analysis of variance except for the TaqI polymorphism, where a Student's $t$-test was performed on the $2 / 2$ homozygote groups vs the $1 / 2,1 / 1$ and $1 / 3$ genotype groups. Degrees of freedom for $\mathrm{F}$-and $t$-values are shown within parentheses.

diabetes. In order to reduce heterogeneity within the Type 2 diabetes group, our study focused on non-obese patients. No association between the RFLP markers and Type 2 diabetes was detected when comparing genotype
${ }^{a}$ IRI, immunoreactive insulin ( 7.18 was used as conversion factor from $\mu \mathrm{U} / \mathrm{ml}$ to $\mathrm{pmol} / \mathrm{l}$ )

${ }^{\mathrm{b}} p<0.05$

distributions in healthy and diabetic individuals. In this context, it is important to consider that population association studies of non-functional DNA markers only will reveal gene defects caused by one or a few mutations. Re- 
Table 8. Glucose and insulin (IRI ${ }^{\mathrm{a}}$ ) concentrations during the glucose infusion test (GIT) in the different Pst1-A genotype groups of 112 healthy subjects

\begin{tabular}{|c|c|c|c|c|c|c|c|c|c|}
\hline \multirow[t]{2}{*}{ Genotype } & \multirow[t]{2}{*}{$n$} & \multirow{2}{*}{\multicolumn{2}{|c|}{$\frac{\text { Fasting glucose }}{(\mathrm{mmol} / \mathrm{l})}$}} & \multicolumn{2}{|c|}{ GIT glucose area } & \multicolumn{2}{|c|}{ GIT glucose area } & \multicolumn{2}{|c|}{ GIT glucose area } \\
\hline & & & & $\times 10^{-2}$ & $0-10 \mathrm{~min}$ & $\times 10^{-2}$ & $10-60 \mathrm{~min}$ & $\times 10^{-2}$ & $60-120 \mathrm{~min}$ \\
\hline \multicolumn{10}{|l|}{ PstI-A } \\
\hline $\mathrm{A} / 3$ & 50 & 4.4 & $F=0.56$ & 1.3 & $F=2.40$ & 8.8 & $\mathrm{~F}=1.16$ & 5.2 & $F=0.04$ \\
\hline $3 / 3$ & 36 & 4.5 & $(2 ; 109)$ & 1.4 & $(2 ; 109)$ & 9.3 & $(2 ; 109)$ & 5.1 & $(2 ; 109)$ \\
\hline Genotype & $n$ & \multicolumn{2}{|c|}{ Fasting IRI ${ }^{\mathrm{a}}$} & \multicolumn{2}{|c|}{ GIT IRI $^{a}$ area } & \multicolumn{2}{|c|}{ GIT IRI $^{\mathrm{a}}$ area } & \multicolumn{2}{|c|}{ GIT IRI $^{\mathrm{a}}$ area } \\
\hline \multicolumn{10}{|l|}{ PstI-A } \\
\hline $\mathrm{A} / \mathrm{A}$ & 26 & 1.1 & & 2.7 & & 17.4 & & 23.1 & \\
\hline $\mathrm{A} / 3$ & 50 & 1.2 & $F=0.79$ & 3.5 & $F=1.73$ & 19.5 & $F=1.32$ & 22.9 & $F=2.15$ \\
\hline $3 / 3$ & 36 & 1.3 & $(2 ; 109)$ & 3.7 & $(2 ; 108)$ & 21.4 & $(2 ; 108)$ & 28.7 & $(2 ; 109)$ \\
\hline
\end{tabular}

Values are arithmetic means for each group. The statistical analysis was made using one-way analysis of variance. Degrees of freedom for $F$-values are shown within parentheses.

cently two studies were published where the problem of genetic heterogeneity was circumvented by screening for mutations in the insulin gene using the polymerase chain reaction $[32,33]$.

One approach to the problem of heterogeneity within the Type 2 diabetic group is to study association between DNA markers and variations in glucose metabolism. Since it is difficult to distinguish between primary and secondary derangements of glucose metabolism in the diabetic state, such studies should preferably be performed in healthy individuals. In our initial study, healthy subjects with certain PstI-A genotypes showed a more pronounced increase in the glucose concentrations during the early phase of the glucose infusion test. In order to confirm this finding, a follow-up study was performed on an additional group of 112 healthy subjects. Our initial finding could, however, not be confirmed. This illustrates the importance of follow-up studies on initial significant findings in genetic association studies.

We conclude from our data that (i) there is a high degree of linkage disequilibrium in the TH/INS/IGF-II region; (ii) no statistically significant association between haplotypes or genotypes and Type 2 diabetes could be demonstrated; and (iii) no significant association between genotypes and variations in glucose metabolism in healthy subjects could be demonstrated. Bearing the limits of population association studies in mind, our findings suggest that the TH/INS/IGF-II region is not likely to be the major susceptibility locus for common forms of Type 2 diabetes in non-obese Scandinavian subjects. However, due to the complexity of the disease, it is difficult to exclude a certain contribution of this locus for insulin deficiency and susceptibility to Type 2 diabetes.

Acknowledgements. We thank Ms M.Olsson for excellent technical assistance and Ms A. Haegermark, for excellent support in collecting family data and blood samples. This work was supported by the Swedish Medical Research Council, the Knut and Alice Wallenberg Foundation, the Swedish Diabetes Association, the Magnus Bergvall Foundation, the King Gustav V and Queen Victoria Foundation, the Hedlund Foundation, the Emil and Wera Cornell Foundation, the Swedish Society for Medical Research, and the Nordic Insulin Foundation.
${ }^{a}$ IRI, immunoreactive insulin (7.18 was used as conversion factor from $\mu \mathrm{U} / \mathrm{ml}$ to $\mathrm{pmol} / \mathrm{l}$ )

\section{References}

1. Barnett AH, Eff C, Leslie RDG, Pyke DA (1981) Diabetes in identical twins. A study of 200 pairs. Diabetologia 20: 87-93

2. Köbberling J, Tillil H(1982) Empirical risk figures for first degree relatives of non-insulin dependent diabetics. In: Köbberling $\mathrm{J}$, Tattersall R (eds) The genetics of diabetes mellitus. Sereno Symposia No 47. Academic Press, London New York, pp 201-209

3. Bell GI, Xiang K, Newman MV et al. (1991) Gene for non-insulin-dependent diabetes mellitus (maturity-onset diabetes of the young subtype) is linked to DNA polymorphism on human chromosome 20q. Proc Natl Acad Sci USA 88: 1484-1488

4. Froguel P, Vaxillaire M, Sun F et al. (1992) Close linkage of glucokinase locus on chromosome $7 p$ to early-onset non-insulindependent diabetes mellitus. Nature 356: 162-164

5. Cerasi E, Luft R (1967) "What is inherited - what is added", hypothesis for the pathogenesis of diabetes mellitus. Diabetes 16: 615-627

6. O'Rahilly SP, Rudenski AS, Burnett MA, Nugent Z, Hosker JP, Darling P (1986) Beta-cell dysfunction, rather than insulin insensitivity, is the primary defect in familial type 2 diabetes. Lancet II: $360-364$

7. Polonsky KS, Given BD, Hirsch LJ et al. (1988) Abnormal patterns of insulin secretion in non-insulin-dependent diabetes mellitus. N Engl J Med 318: 1231-1239

8. Mitrakou A, Kelley D, Mokan M et al. (1992) Role of reduced suppression of glucose production and diminished early insulin release in impaired glucose tolerance. $\mathrm{N}$ Engl J Med 326: 22-28

9. Iselius L, Lindsten J, Morton NE et al. (1985) Genetic regulation of the kinetics of glucose-induced insulin release in man. Clin Genet 28: 8-15

10. Bell GI, Horita S, Karam JH (1984) A polymorphic locus near the human insulin gene is associated with insulin-dependent diabetes mellitus. Diabetes 33:176-183

11. Elbein S, Rotwein P, Permutt MA, Bell GI, Sanz N, Karam JH (1985) Lack of association of the polymorphic locus in the $5^{\prime}$ flanking region of the human insulin gene and diabetes in American blacks. Diabetes 34: 433-439

12. Cocozza S, Riccardi G, Monticelli A et al. (1988) Polymorphism an the 5 ' end flanking region of the insulin gene is associated with reduced insulin secretion in healthy individuals. Eur J Clin Invest 18: 582-586

13. Bell GI, Gerhard DS, Fong NM, Sanchez-Pescador R, Rall LB (1985) Isolation of the human insulin-like growth factor genes: insulin-like growth factor II and insulin genes are contiguous. Proc Natl Acad Sci USA 82: 6450-6454

14. O'Malley KL, Rotwein P (1988) Human tyrosine hydroxylase and insulin genes are contiguous on chromosome 11. Nucleic Acids Res 16: $4437-4446$ 
15. Chakravarti A, Elbein SC, Permutt MA (1986) Evidence for increased recombination near the human insulin gene: implication for disease association studies. Proc Natl Acad Sci USA 83: 10451049

16. Cox NJ, Bell GI, Xiang K (1988) Linkage disequilibrium in the human insulin/insulin-like growth factor II region of human chromosome 11. Am J Hum Genet 43: 495-501

17. Xiang K, Cox NJ, Sanz N, Huang P, Karam JH, Bell GI (1989) Insulin-receptor and apolipoprotein genes contribute to development of NIDDM in Chinese Americans. Diabetes 38: $17-23$

18. Sten-Linder M, Vilhelmsdotter S, Wedell A et al. (1991) Screening for insulin receptor gene DNA polymorphisms associated with glucose intolerance in a Scandinavian population. Diabetologia 34: 265-270

19. Wajngot A, Luft R, Efendic S (1983) Oral glucose tolerance test and insulin sensitivity in low insulin responders. Acta Endocrinol 104: $77-84$

20. Bell GI, Selby MJ, Rutter WJ (1982) The highly polymorphic region near the human insulin gene is composed of simple tandemly repeating sequences. Nature 295: 31-35

21. Elbein SC, Corsetti L, Permutt MA (1985) New polymorphisms at the insulin locus increase its usefulness as a genetic marker. Diabetes 34: 1139-1144

22. Xiang K, Karam JH, Bell GI (1987) BamHI RFLP at the insulinlike growth factor II (IGF2) locus on chromosome 11. Nucleic Acids Res 15: 7655

23. Kelsoe JR, Stubblefield BK, Ginns EI (1988) Human tyrosine hydroxylase (TH) genomic fragment (pHGTH4) identifies a PstI polymorphism. Nucleic Acids Res 16: 7760

24. Xiang K, Cox NJ, Bell GI (1988) ApaI and SstI RFLPs at the insulin-like growth factor II (IGF2) locus on chromosome 11. Nucleic Acids Res 16:3599

25. Sten-Linder M, Granquist M, Stern I, Bell GI, Luthman H (1989) Dral and Pstl RFLPs in the tyrosine hydroxylase (TH) and insulin gene (INS) region of chromosome 11. Nucleic Acids Res 17: 5873

26. Bell GI, Karam JH, Rutter WJ (1981) Polymorphic DNA region adjacent to the $5^{\prime}$ end of the human insulin gene. Proc Natl Acad Sci USA 78: 5759-5763

27. Southern EM (1975) Detection of specific sequences among DNA fragments separated by gel electrophoresis. J Mol Biol 98: 503-517

28. Lewontin RC (1964) The interaction of selection and linkage. I. General considerations: heterotic models. Genetics 49:49-67

29. Hedrick PW (1987) Gametic disequilibrium measures: proceed with caution. Genetics 117: 331-341
30. Sten-Linder M, Olsson M, Iselius L, Efendic S, Luthman H (1991) DNA haplotype analysis suggests linkage disequilibrium in the human insulin receptor gene. Hum Genet 87: 469-474

31. Wolff RK, Plaetke R, Jeffreys AJ, White R (1989) Unequal crossingover between homologous chromosomes is not the major mechanism involved in the generation of new alleles at VNTR loci. Genomics 5: 382-384

32. Olansky L, Welling C, Giddings $S$ et al. (1992) A variant insulin promoter in non-insulin-dependent diabetes mellitus. J Clin Invest $89: 1596-1602$

33. Olansky L, Janssen R, Welling C, Permutt MA (1992) Variability of the insulin gene in American blacks with NIDDM. Analysis by single-strand conformational polymorphisms. Diabetes 41: 742749

34. Bell GI, Merryweather JP, Sanchez-Pescador R et al. (1984) Sequence of a cDNA clone encoding human preproinsulin-like growth factor II. Nature 310:775-781

35. de Pagter-Holthuizen P, van Schaik FMA, Verduijn GM et al. (1986) Organization of the human genes for insulin-like growth factors I and II. FEBS Lett 195: 179-184

36. Gray A, Tam AW, Dull TJ et al. (1987) Tissue-specific and developmentally regulated transcription of the insulin-like growth factor 2 gene. DNA 6: 283-295

37. O'Malley KL, Anhalt MJ, Martin BM, Kelsoe JR, Winfield SL, Ginns EI (1987) Isolation and characterization of the human tyrosine hydroxylase gene: identification of $5^{\prime}$ alternative splice sites responsible for multiple mRNAs. Biochemistry 26: 69106914

38. de Pagter-Holthuizen P, Jansen M, van der Kammen RA, van Schaik FMA, Sussenbach JS (1988) Differential expression of the human insulin-like growth factor II gene. Characterization of the IGF-II mRNAs and an mRNA encoding a putative IGF-IIassociated protein. Biochim Biophys Acta 950: 282-295

39. Holthuizen P, van der Lee FM, Ikejiri K, Yamamoto M, Sussenbach JS (1990) Identification and initial characterization of a fourth leader exon and promoter of the human IGF-II gene. Biochim Biophys Acta 1087: 341-343

Received: 22 April 1992

and in revised form: 18 August 1992

Dr. H.Luthman

Department of Clinical Genetics

Karolinska Institute

Karolinska Hospital

S-104 01 Stockholm

Sweden 